\title{
Effect of Calcinations Temperature on Crystallography and Nanoparticles in ZnO Disk
}

\author{
Urai Seetawan $^{1}$, Suwit Jugsujinda ${ }^{1}$, Tosawat Seetawan ${ }^{1 *}$, Ackradate Ratchasin ${ }^{1}$, \\ Chanipat Euvananont ${ }^{2}$, Chabaipon Junin ${ }^{2}$, Chanchana Thanachayanont ${ }^{2}$, Prasarn Chainaronk ${ }^{3}$
}

${ }^{1}$ Thermoelectrics Research Center, Faculty of Science and Technology, Sakon Nakhon Rajabhat University, Sakon Nakhon, Thailand; ${ }^{2}$ National Metal and Materials Technology Center, National Science and Technology Development Agency, Pathumthani, Thailand; ${ }^{3}$ Program of Physics, Faculty of Science, Ubonratchathani Rajabhat University, Ubon Ratchathani, Thailand.

Email: ${ }^{*}$ _seetawan@snru.ac.th

Received April 22 ${ }^{\text {nd }}, 2011$; revised May 30 $0^{\text {th }}, 2011$; accepted June $7^{\text {th }}, 2011$.

\begin{abstract}
We proposed a good calcinations condition of the $\mathrm{ZnO}$ disk to control the crystallography and nanoparticles in $\mathrm{ZnO}$ disk. The crystallography of precursor powder and disk powder were analyzed by the X-ray diffraction (XRD). The mean nanoparticles of $\mathrm{ZnO}$ disk was determinate by XRD results and observed by scanning electron microscope. The temperature ranges of $400^{\circ} \mathrm{C}$ to $650^{\circ} \mathrm{C}$ in air for 30 minutes were used calcinations $Z n O$ disk. These temperature can be controlled the single phase, lattice parameters, unit cell volume, crystalline size, $d$-value, texture coefficient and bond lengths of $Z n-Z n, Z n-O$ and $O-O$ which correspond significantly the hexagonal crystal structure. The nanoparticles were small changed mean of $76.59 \mathrm{~nm}$ at the calcinations temperature range.
\end{abstract}

Keywords: Nanoparticles in ZnO Disk, Calcinations Temperature, Crystallography of ZnO

\section{Introduction}

Zinc oxide nanomaterials are interesting and have been developed in recent years because of their physical and chemical properties, which promote an achievement of high performance materials for various applications. Recently, many studies have been made in order to understand the microstructure, electrical properties and thermoelectric properties of $\mathrm{ZnO}$ for application. For examples, the varistor ceramics [1], luminescent materials [2], new coplanar gas sensor array [3], application of sunscreen nanoparticles [4] and, finally, impure $\mathrm{ZnO}$ materials are of great interest for high temperature thermoelectric application [5].

In this work, we report an analysis the effect of calcinations temperature on phase identification, lattice parameters, crystal structure, orientation, texture coefficient, bond length of $\mathrm{Zn}-\mathrm{Zn}, \mathrm{Zn}-\mathrm{O}$ and $\mathrm{O}-\mathrm{O}$, powder distribution and powder size in $\mathrm{ZnO}$ disk for control the nanopowder in $\mathrm{ZnO}$ disk or tendency apply the $\mathrm{ZnO}$ disk to thermoelectric material.

\section{Experimental}

The $\mathrm{ZnO}$ precursor of nanopowder was synthesized by direct precipitation method using $\mathrm{Zn}\left(\mathrm{NO}_{3}\right)_{2} \cdot 6 \mathrm{H}_{2} \mathrm{O}\left(\mathrm{QRëC} \mathrm{C}^{\mathrm{TM}}\right.$,
98.5\% purity), $\left(\mathrm{NH}_{4}\right)_{2} \mathrm{CO}_{3} \quad$ (QRëC $\mathrm{QM}^{\mathrm{TM}}, 99.5 \%$ purity), ethanol, and de-ionized water. Firstly, $\mathrm{Zn}\left(\mathrm{NO}_{3}\right)_{2} \cdot 6 \mathrm{H}_{2} \mathrm{O}$ and $\left(\mathrm{NH}_{4}\right)_{2} \mathrm{CO}_{3}$ were dissolved in de-ionized water by the vigorously stirring to form solutions with 1.5 and $2.25 \mathrm{~mol} / \mathrm{L}$ concentrations, respectively. Secondly, the precipitates obtained by the reaction between the $\mathrm{Zn}\left(\mathrm{NO}_{3}\right)_{2}$ and the $\left(\mathrm{NH}_{4}\right)_{2} \mathrm{CO}_{3}$ solutions were collected by filtration and rinsed three times with de-ionized water and ethanol, respectively, then washed and dried at $80^{\circ} \mathrm{C}$ to form the precursor of nanopowder. The calcinations temperature was investigated by the relationship between the weight loss and temperature by using thermal gravimetric analysis (TGA-DTA/DSC; NETZSCH STA 449C). Finally, the precursor of nanopowder was pressured by the hydraulic press about $160 \mathrm{MPa}$ in air to obtain the $\mathrm{ZnO}$ disk. The disk was calcinated at temperature range $400^{\circ} \mathrm{C}$ to $650^{\circ} \mathrm{C}$ in air for 30 minutes. The crystallography of precursor of powder and disk powder were analyzed by X-ray diffraction (XRD; PW1710) with a $\mathrm{Cu}-\mathrm{K} \alpha 1(\lambda=0.15406 \mathrm{~nm})$ source at $40 \mathrm{kV}$ and $30 \mathrm{~mA}$. The morphology of the precursor of powder and disk powder were observed by a scanning electron microscope (SEM; JSM-6100). The particle size $(D)$ of precursor and disk powder were calculated by the Debye- 
Scherrer formula using raw data from XRD patterns and evaluated from SEM images. The crystalline size was calculated by the Debye-Scherrer formula as follows.

$$
D=\frac{0.89 \lambda}{\beta \cos \theta_{0}}
$$

where $D$ is the crystalline size (in $\mathrm{nm}$ ), $\lambda$ is the wavelength (in $\mathrm{nm}$ ), $\beta$ is the full width at half maximum (FWHM-in radian) intensity, and $\theta$ is the Bragg diffraction angle [6]. The relative percentage error for all the disks was evaluated by the Equation (2) and JCPDS standard $d$-values [7].

$$
\text { Relative percentage error }=\frac{\left|Z_{H}-Z\right|}{Z} \times 100
$$

where $Z_{H}$ is the actual obtained $d$-value in XRD patterns and $Z$ is the standard $d$-value in JCPDS data. The particular plane and information were concerned by the preferential crystallite orientation determined from the texture coefficient $T C(h k l)$ [8] as follows:

$$
T C(h k l)=\frac{I(h k l) / I_{0}(h k l)}{N^{-1} \sum_{n} I(h k l) / I_{0}(h k l)} \times 100 \%
$$

where $I(h k l)$ is the measured relative intensity of a plane $(h k l)$, and $I_{0}(h k l)$ is the standard intensity of the plane taking from the JCPDS data $[9,10]$. The $\mathrm{Zn}-\mathrm{O}$ bond length $(L)$ is given by

$$
L=\sqrt{\frac{a^{2}}{3}+c^{2}\left(\frac{1}{2}-u\right)^{2}}
$$

where the parameter $u$ is defined by $u=\frac{a^{2}}{3 c^{2}}+0.25$, $a$ and $b$ are lattice parameters [11]. The unit cell structure was designed by discrete variational $\mathrm{X} \alpha$ method for evaluating $\mathrm{Zn}-\mathrm{O}$ bond length [12]. The volume of hexagonal primitive cell is $\left(\frac{\sqrt{3}}{2}\right) a^{2} c$ and Brillouin zone is $(2 \pi)^{3} V_{c}$ where $V_{c}$ is the volume of a crystal primitive cell [13].

\section{Results and Discussion}

The TGA curve shows a weight loss step at incremented temperatures from $25^{\circ} \mathrm{C}$ to $1000^{\circ} \mathrm{C}$ as shown in Figure 1 . The weight loss was related to the decomposition of the precursor of powder. The clear plateau was formed in a temperature range between $435^{\circ} \mathrm{C}$ and $650^{\circ} \mathrm{C}$ on the TGA curve indicate the calcinations temperature range to control weight loss and save $\mathrm{ZnO}$ disk. No further weight loss and no thermal effect were observed at temperatures

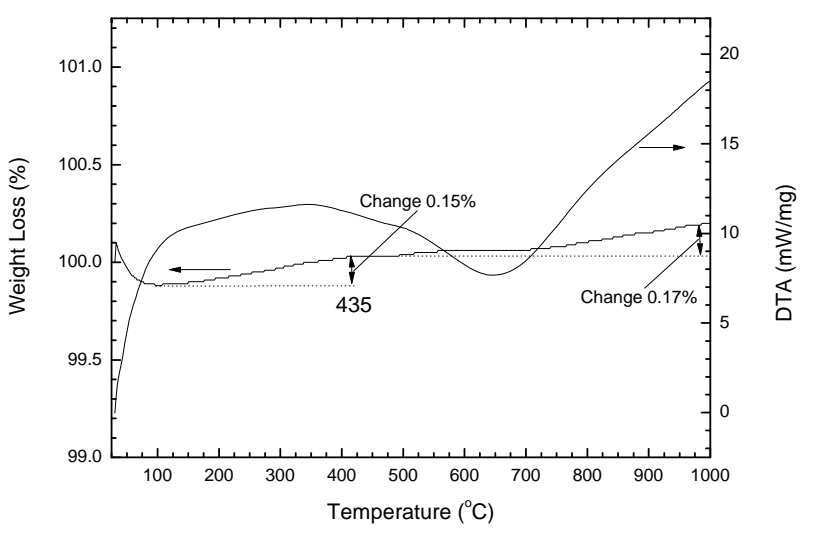

Figure 1. TGA-DTA traces at a heating rate of $10^{\circ} \mathrm{C} / \mathrm{min}$ for $\mathrm{ZnO}$ precursor of powder.

range $435^{\circ} \mathrm{C}$ to $500^{\circ} \mathrm{C}$ indicating that decomposition does not occur above this temperature and the stable nanoparticles. The XRD patterns of the precursor of powder were corresponded the patterns of JCPDS Card No.891397. The precursor of powder has been the lattice parameters $a=b=3.2481 \AA, c=5.2049 \AA$ indicate hexagonal structure.

Therefore, we should the temperature range of $400^{\circ} \mathrm{C}$ to $700^{\circ} \mathrm{C}$ for calcinations the $\mathrm{ZnO}$ disk to control the nanoparticles. However, the disk has agglomerated powder and cracked at $700^{\circ} \mathrm{C}$.

The XRD patterns of the disk powder were calcinated at temperatures of $400^{\circ} \mathrm{C}, 450^{\circ} \mathrm{C}, 500^{\circ} \mathrm{C}, 550^{\circ} \mathrm{C}, 600^{\circ} \mathrm{C}$ and $650^{\circ} \mathrm{C}$ in air for 30 minutes are shown in Figure 2(a)2(f), respectively. The main peaks correspond to the hexagonal structure $\mathrm{ZnO}$ and the lattice constants $a=b=$ $3.2469 \AA$ increase to $3.2488 \AA$ and $c=5.2049 \AA$ slightly decrease to $5.2031 \AA$ as shown in Figure 3.

The values of $c / a$ and unit cell volume were corresponded to literature data [14-17] as shown in Figure 4.

The full widths at half maxima (FWHM) of the (100), (002) and (101) index planes of 0.256, 0.256 and 0.26 $\mathrm{nm}$, respectively, were uses for particle size calculation. The $d$-values, $d \%$ error and texture coefficient calculated by using Equation (2) and (3) are shown in Table 1.

The average relative percentage errors of calcinations temperatures of $400^{\circ} \mathrm{C}, 450^{\circ} \mathrm{C}, 500^{\circ} \mathrm{C}, 550^{\circ} \mathrm{C}, 600^{\circ} \mathrm{C}$ and $650^{\circ} \mathrm{C}$ are $0.17 \%, 0.77 \%, 0.28 \%, 0.18 \%, 0.59 \%$, and $0.29 \%$, respectively. The experimental $d$-values and JCPDS $d$-values are in a good agreement and indicate hexagonal structure [9].

The texture coefficient $(T C(h k l))$ values were calculated by Equation (3) and obtain a mean value of 0.35 . The value $T C(h k l)=1$ represents randomly oriented crystallites, while higher values indicate the abundance of grains oriented in a given $(h k l)$ direction. According 


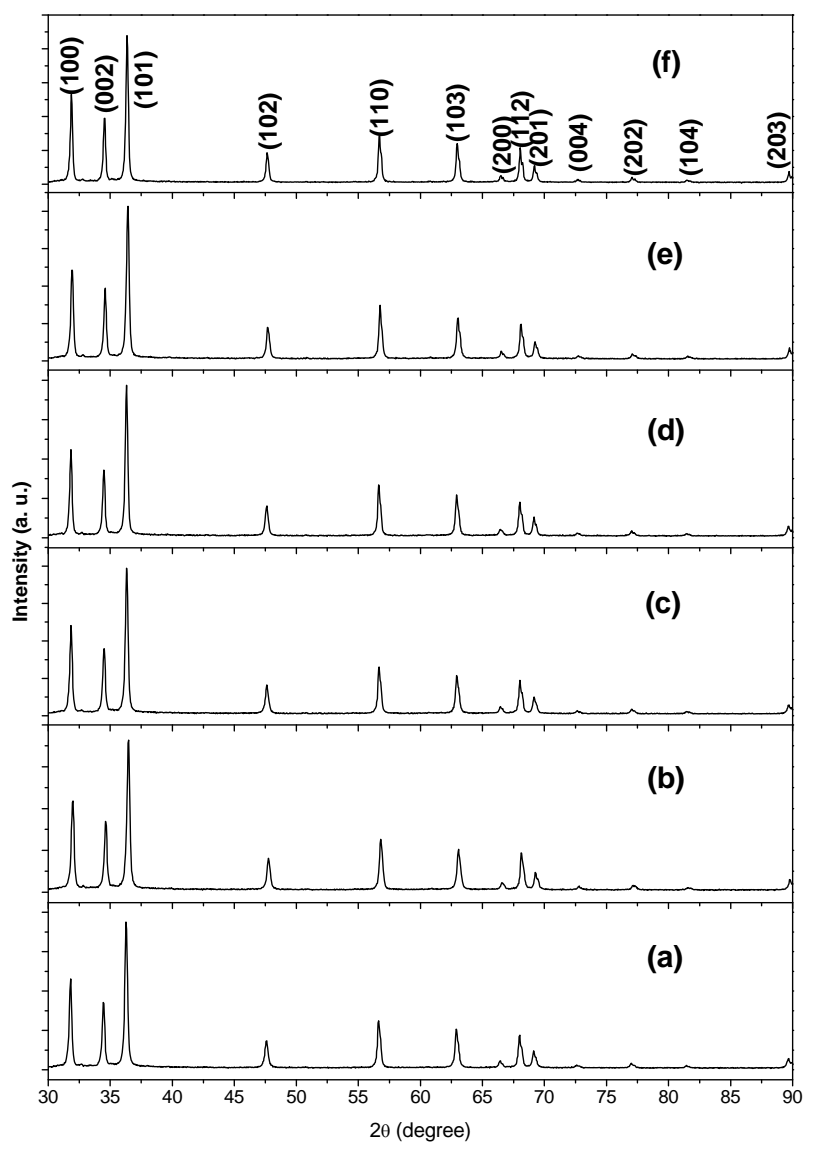

Figure 2. XRD patterns of disk $\mathrm{ZnO}$ powder calcinated at (a) $400^{\circ} \mathrm{C}$, (b) $450^{\circ} \mathrm{C}$, (c) $500^{\circ} \mathrm{C}$, (d) $550^{\circ} \mathrm{C}$, (e) $600^{\circ} \mathrm{C}$ and (f) $650^{\circ} \mathrm{C}$.

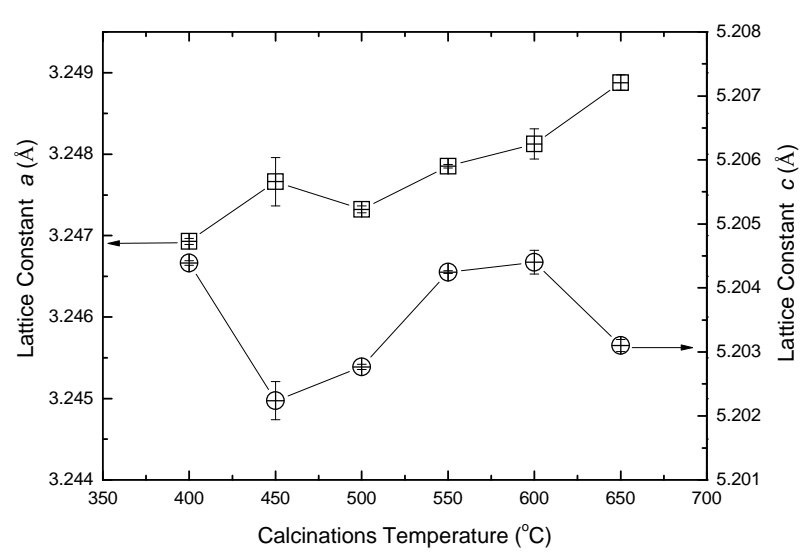

Figure 3. The calcinations temperature dependence on the lattice constants, $a$ and $c$.

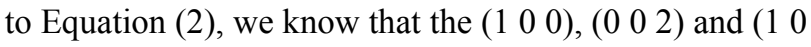
1) planes were the preferential crystallite orientation for the nanopowder of $\mathrm{ZnO}$ fabricated in this work. The $T C$ $(h k l)$ represents the texture of a particular plane, whose deviation from unity implies the preferred growth [18]. It

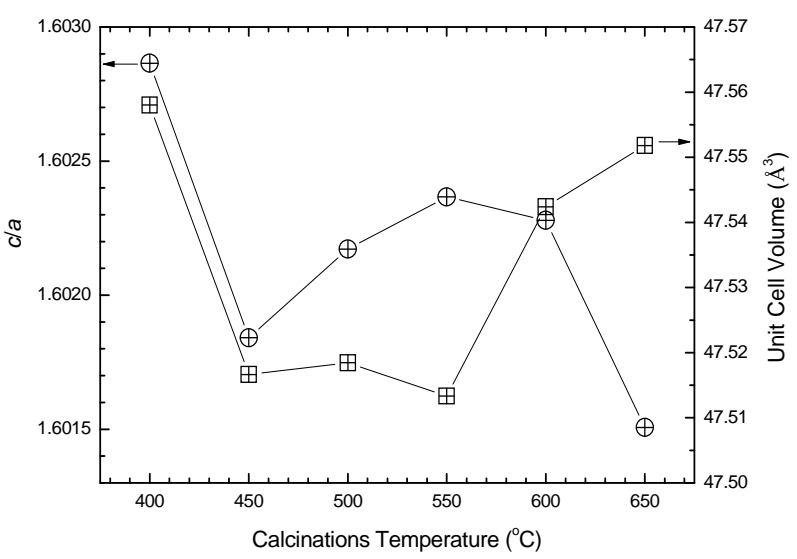

Figure 4. The calcinations temperature dependence on the ratio of $c / a$ lattice constants and unit cell volume.

Table 1. 28, $d$-value, calculation $d \%$ error and texture coefficient of the (101) for disk $\mathrm{ZnO}$ powder after calcinations.

\begin{tabular}{ccccc}
\hline Sin. Temp. & $2 \theta$ & $\mathrm{d}(\AA)$ & $\mathrm{d}(\%)$ & $\mathrm{TC}$ \\
\hline 400 & 36.277 & 2.4743 & 0.17 & 0.32 \\
450 & 36.504 & 2.4594 & 0.77 & 0.38 \\
500 & 36.317 & 2.4716 & 0.28 & 0.32 \\
550 & 36.282 & 2.474 & 0.18 & 0.33 \\
600 & 36.398 & 2.4663 & 0.59 & 0.33 \\
650 & 36.324 & 2.4712 & 0.29 & 0.32 \\
\hline
\end{tabular}

can be seen that the highest $T C$ was in the (101) plane for nanopowder in $\mathrm{ZnO}$ disk at $450^{\circ} \mathrm{C}$ [19].

The bond lengths of $\mathrm{Zn}-\mathrm{Zn}, \mathrm{Zn}-\mathrm{O}$ and $\mathrm{O}-\mathrm{O}$ are shown in Table 2, where the $\mathrm{Zn}-\mathrm{O}$ bond length is $1.9767 \AA$ in the unit cell of $\mathrm{ZnO}$ and neighboring atoms. Viewing direction is approximately parallel to $\mathrm{O}^{2-}$ and $\mathrm{Zn}^{2+}$ corresponding to literature data [20] and have a good thermoelectric power about $-279 \mu \mathrm{V} / \mathrm{K}$ at $500^{\circ} \mathrm{C}$ [21] which is close to the proposed calcinations temperature range.

The SEM images of nanopowder in $\mathrm{ZnO}$ disk after calcinations temperature of $400^{\circ} \mathrm{C}, 450^{\circ} \mathrm{C}, 500^{\circ} \mathrm{C}, 550^{\circ} \mathrm{C}$, $600^{\circ} \mathrm{C}$ and $650^{\circ} \mathrm{C}$, respectively are shown in Figure 5(a)$5(f)$.

The nanopowder of $\mathrm{ZnO}$ was exhibited a good distribution after being calcinated below $550^{\circ} \mathrm{C}$. The powder of $\mathrm{ZnO}$ was covered with nanopowder, while other portions retained the smooth morphology. The particle sizes were small increased from 73.50 to $79.67 \mathrm{~nm}$ with increasing calcinations temperature as shown in Figure 6. However, the nanopowder was agglomerated to form larger particle sizes at the calcinations temperature higher than $650^{\circ} \mathrm{C}$ and disk fractured at $700^{\circ} \mathrm{C}$. 
Table 2. The bond length lists of $\mathrm{ZnO}$ compound.

\begin{tabular}{cccccc}
\hline & $1^{\text {th }}(\AA)$ & $2^{\text {nd }}(\AA)$ & $3^{\text {th }}(\AA)$ & $4^{\text {th }}(\AA)$ & $5^{\text {th }}(\AA)$ \\
\hline $\mathrm{Zn}-\mathrm{Zn}$ & 3.2138 & 3.2568 & 4.5755 & 5.2125 & 5.6162 \\
$\mathrm{Zn}-\mathrm{O}$ & 1.9767 & 1.9959 & 3.2166 & 3.8099 & 3.8197 \\
$\mathrm{O}-\mathrm{O}$ & 3.2138 & 3.2568 & 4.5755 & 5.2125 & 5.6162 \\
\hline
\end{tabular}
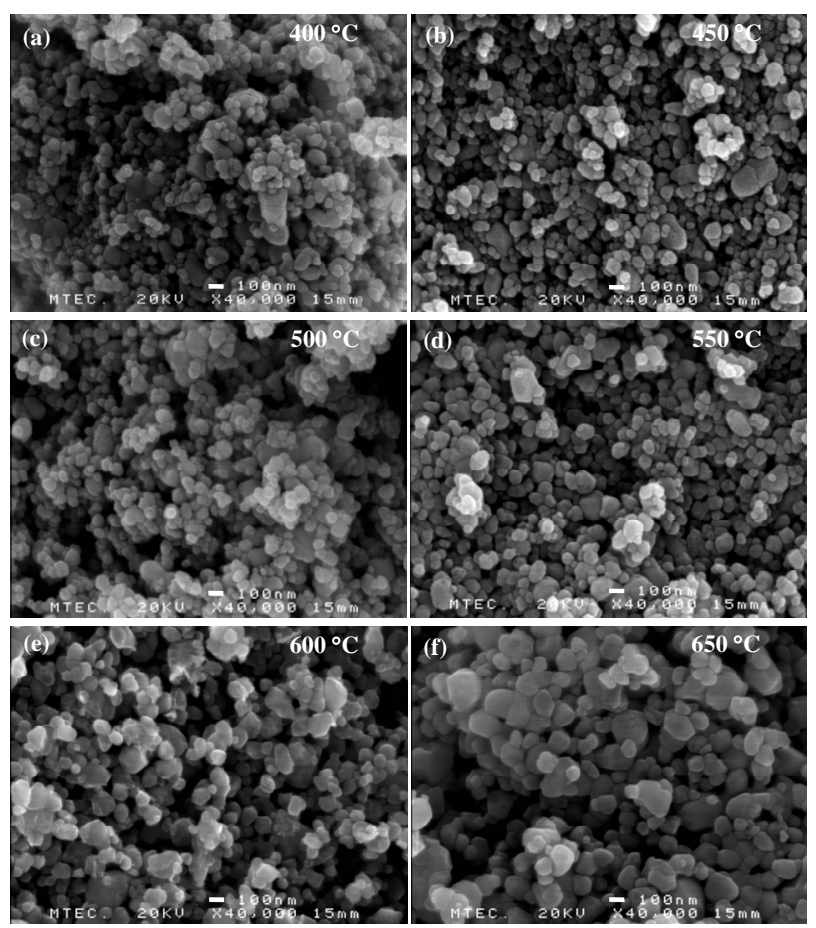

Figure 5. SEM morphology of $\mathrm{ZnO}$ disk powder after calcinated at (a) $400^{\circ} \mathrm{C}$, (b) $450^{\circ} \mathrm{C}$, (c) $500^{\circ} \mathrm{C}$, (d) $550^{\circ} \mathrm{C}$, (e) $600^{\circ} \mathrm{C}$ and (f) $650^{\circ} \mathrm{C}$.

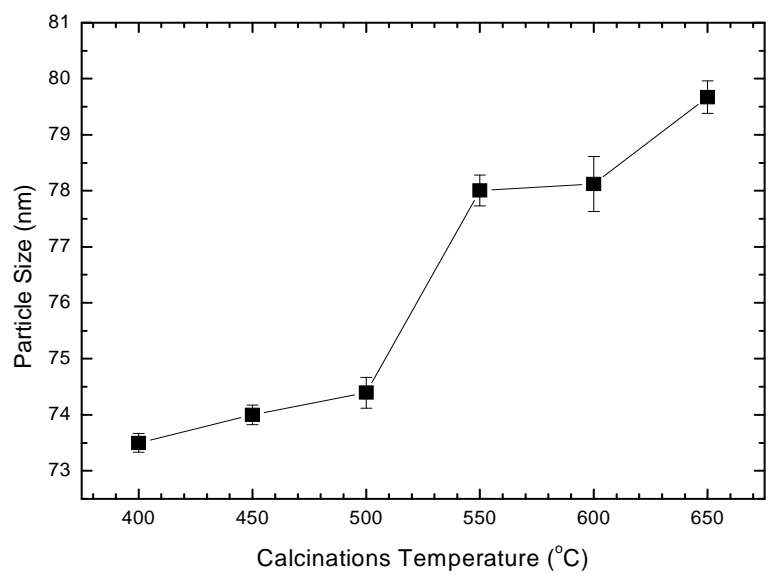

Figure 6. The calcinations temperature dependence on particle sizes of $\mathrm{ZnO}$ disk powder.

\section{Conclusions}

The temperature range of $400^{\circ} \mathrm{C}$ to $650^{\circ} \mathrm{C}$ was chosen for calcinations temperature and controled the nanoparticle in $\mathrm{ZnO}$ disk. The crystallography of disk powder was corresponding to the hexagonal structure and the lattice constants. The experimental $d$-values were in a good agreement with JCPDS I and indicated the hexagonal structure. The $\mathrm{Zn}-\mathrm{O}$ bond length of $1.9767 \AA$ was related with $\mathrm{ZnO}$ unit cell viewed direction approximate parallel to $\mathrm{O}^{2-}$ and $\mathrm{Zn}^{2+}$. The disk powder was exhibited good distribution after being calcinated below $550^{\circ} \mathrm{C}$ covering with the nanoparticles, while other portions retained the smooth morphology and the mean particle size of 76.59 .

\section{Acknowledgements}

Financial support was provided by the Electricity Generating Authority of Thailand, EGAT (52-2115-043-JOB No. 803-SNRU).

\section{REFERENCES}

[1] D. Xu, X. F. Shi, X. N. Cheng, J. Yang, Y. E. Fan, H. M. Yuan and L. Y. Shi, "Microstructure and Electrical Properties of $\mathrm{Lu}_{2} \mathrm{O}_{3}$-Doped $\mathrm{ZnO}-\mathrm{Bi}_{2} \mathrm{O}_{3}$-Based Varistor Ceramics," Transactions of Nonferrous Metals Society of China, Vol. 20, No. 12, December 2010, pp. 2303-2308. doi:10.1016/S1003-6326(10)60645-0

[2] N. Hagura, T. Ogi, T. Shirahama, F. Iskandar and K. Okuyama, "Highly luminescent Silica-Coated ZnO Nanoparticles Dispersed in Anaqueousmedium," Journal of Luminescence, Vol. 131, No. 5, May 2011, pp. 921-925. doi:10.1016/j.jlumin.2010.12.024

[3] C. Li, S. Zhang, M. Hu and C. Xie, "Nanostructural ZnO Based Coplanar Gas Sensor Arrays from the Injection of Metal Chloride Solutions: Device Processing, Gas-Sensing Properties and Selectivity in Liquors Applications," Sensors and Actuators B, Vol. 153, No. 2, April 2011, pp. 415-420. .doi:10.1016/j.snb.2010.11.008

[4] A. P. Popov, A. V. Priezzhev, J. Lademann and R. Myllylä, "Alteration of Skin Light-Scattering and Absorption Properties by Application of Sunscreen Nanoparticles: A Monte Carlo Study," Journal of Quantitative Spectroscopy \& Radiative Transfer, 2011, Article in Press.

[5] X. Qu, W. Wang, S. Lva and D. Jia, "Thermoelectric Properties and Electronic Structure of Al-Doped ZnO," Solid State Communications, Vol. 151, No. 4, February 2011, pp. 332-336. doi:10.1016/j.ssc.2010.11.020

[6] C. Chen, B. Yu, J. Liu, Q. Dai and Y. Zhu, "Investigation of $\mathrm{ZnO}$ Films on $\mathrm{Si}(111)$ Substrate Grown by Low Energy O+ Assisted Pulse Laser Deposited Technology," Material Letters, Vol. 61, No. 14-15, June 2007, pp. 2961-2964.

[7] D. P. Padiyan and A. Marikani, "X-Ray Determination of Lattice Constants of $\mathrm{Cd}_{\mathrm{X}} \mathrm{Sn}_{1-\mathrm{X}} \mathrm{Se}$ Mixed Crystal Systems," Crystal Research and Technology, Vol. 37, No. 11, November 2002, pp. 1241-1248.

doi:10.1002/1521-4079(200211)37:11<1241::AID-CRAT 1241>3.0.CO;2-C 
[8] C. S. Barret, T. B. Massalski, "Structure of Metals," Pergamon Press, Oxford, 1980.

[9] Joint Committee on Powder Diffraction Standards, Powder Diffraction File, Card No: 891397.

[10] H. Schulz and K. H. Thiemann, "Structure Parameters and Polarity of the Wurtzite Type Compounds Sic-2H and ZnO," Solid State Communications, Vol. 32, No. 9, December 1997, pp. 783-785.

[11] S. Aksoy, Y. Caglar, S. Ilican and M. Caglar, "Effect of Deposition Temperature on the Crystalline Structure and Surface Morphology of ZnO Films Deposited on p-Si," Advances in Control, Chemical Engineering, Civil Engineering and Mechanical Engineering, ISBN: 978-960-474-251-6, pp. 227-231.

[12] H. Adachi, M. Tsukada and C. Satoko, "Discrete Variational X $\alpha$ Cluster Calculations. I. Application to Metal Clusters," Journal of the Physics Society of Japan, Vol. 45, April 1978, pp. 875-883.

[13] C. Kittel, "Introduction to Solid State Physics," 8th Edition, John Wiley \& Sons, New York, 2005.

[14] R. Chowdhury, P. Rees, S. Adhikari, F. Scarpa and S. P. Wilks, "Electronic Structures of Silicon Doped ZnO," Physica B, Vol. 405, No. 8, April 2010, pp. 1980-1985. doi:10.1016/j.physb.2010.01.084

[15] S. Panpan, S. Xiyu, H. Qinying, L. Yadong and C. Wei, "First-Principles Calculation of the Electronic Band of
ZnO Doped with C," Journal of Semiconductors, Vol. 30, No. 5, May 2009, pp. 052001-1-052001-4.

[16] E. H. Kisi and M. M. Elcombe, " $u$ Parameters for the Wurtzite Structure of $\mathrm{ZnS}$ and $\mathrm{ZnO}$ Using Powder Neutron Diffraction," Acta Crystallographica Section CCrystal Structure Communications Vol. 45, No. 12, December 1989, pp. 1867-1870.

[17] J. L. Lyons, A. Janotti and C. G. Van de Walle, "Role of $\mathrm{Si}$ and Ge as Impurities in ZnO," Physical Review B, Vol. 80, No. 20, November 2009, pp. 205113-2051117. doi:10.1103/PhysRevB.80.205113

[18] C. S. Barret and T. B. Massalski, "Structure of Metals," Pergamon Press, Oxford, 1980.

[19] S. Ilican, M. Caglar and Y. Caglar, "Determination of the Thickness and Optical Constants of Transparent IndiumDoped ZnO Thin Films by the Envelope Method," Materials Science-Poland, Vol. 25, No. 3, April 2007, pp. 709-718.

[20] O. Altuntasoglu, Y. Matsuda, S. Ida and Y. Matsumoto, "Syntheses of Zinc Oxide and Zinc Hydroxide Single Nanosheets," Chemistry of Materials, Vol. 22, No.10, April 2010, pp. 3158-3164. doi:10.1021/cm100152q

[21] X. Qu, W. Wang, S. Lv and D. Jia, "Thermoelectric Properties and Electronic Structure of Al-Doped ZnO," Solid State Communications, Vol. 151, No. 4, February 2011, pp. 332-336. doi:10.1016/j.ssc.2010.11.020 